\title{
HUBUNGAN MINAT BELAJAR DAN PENGETAHUAN MENGGAMBAR TEKNIK DENGAN HASIL BELAJAR MENGGAMBAR DENGAN PERANGKAT LUNAK PADA SISWA KELAS XI PROGRAM KEAHLIAN TEKNIK GAMBAR BANGUNAN SMK NEGERI 1 LUBUK PAKAM
}

\author{
Robianto Situmorang ${ }^{1)}$ Dan Edim Sinuraya ${ }^{2)}$ \\ Email : edimsinuraya@yahoo.com
}

\begin{abstract}
Abstrak
Penelitian ini bertujuan untuk mengetahui: 1) Adanya hubungan yang positif dan berarti antara Minat Belajar terhadap hasil belajar Menggambar Dengan Perangkat Lunak, 2) Adanya hubungan yang positif dan berarti antara Pengetahuan Menggambar Teknik terhadap hasil belajar Menggambar Dengan Perangkat Lunak, 3) Adanya hubungan yang positif dan berarti antara Minat Belajar dan Pengetahuan Menggambar Teknik terhadap hasil belajar Menggambar Dengan Perangkat Lunak pada siswa kelas XI Program Keahlian Teknik Gambar Bangunan SMK Negeri 1 Lubuk Pakam Tahun Ajaran 2014/2015.

Sebelum penelitian ini dilakukan instrumen penelitian terlebih dahulu diujicobakan, dilanjutkan dengan uji validitas, reliabelitas, indeks kesukaran, dan daya pembeda soal. 1) Hasil uji coba angket Minat Belajar diperoleh 24 butir dari 30 butir yang diujicobakan dengan koefisien reliabelitas $=0,861$ dan termasuk kategori sangat tinggi. 2) Hasil uji coba soal tes Pengetahuan Menggambar Teknik diperoleh 20 butir soal dari 30 butir yang diujicobakan, koefisien reliabelitas $=0,9$ dan termasuk kategori sangat tinggi, indeks kesukaran terdapat 6 butir kategori soal mudah, 11 butir soal sedang dan 3 soal kategori sukar, dan daya beda soal terdapat 12 butir soal dalam kategori baik, 8 butir soal dalam kategori cukup. 3) Hasil uji coba soal tes Menggambar Dengan Perangkat Lunak diperoleh 26 butir soal dari 32 butir yang diujicobakan, koefisien reliabelitas $=0,762$ dan termasuk kategori tinggi, indeks kesukaran terdapat 10 butir kategori soal mudah, 14 butir soal sedang dan 2 soal kategori sukar, dan daya beda soal terdapat 10 butir soal dalam kategori baik, 9 butir soal dalam kategori cukup dan 7 butir soal dalam kategori jelek.

Berdasarkan pengujian hipotesis dapat disimpulkan: 1) Terdapat hubungan yang positif dan berarti antara Minat Belajar dengan hasil belajar Menggambar Dengan Perangkat Lunak dengan besar korelasi $r_{\mathrm{X} 1 \mathrm{Y}}=$ $0,441>\mathrm{r}_{\text {tabel }}=0,349$ dan $\mathrm{t}_{\text {hitung }}=3,000>\mathrm{t}_{\text {tabel }}=1,696$ dan dari korelasi parsial diperoleh $\mathrm{r}_{\mathrm{Y}(1,2)}=0,523>$ rtabel $=0,349$ dan $t_{\text {hitung }}=3,305>t_{\text {tabel }}=1,696$. 2) Terdapat hubungan yang positif dan berarti antara Pengetahuan Menggambar Teknik dengan hasil belajar Menggambar Dengan Perangkat Lunak dengan besar korelasi $\mathrm{r}_{\mathrm{X} 2 \mathrm{Y}}=0,450>\mathrm{r}_{\text {tabel }}=0,349$ dan $\mathrm{t}_{\text {hitung }}=3,093>\mathrm{t}_{\text {tabel }}=1,696$ dan dari korelasi parsial diperoleh $r_{Y(1,2)}=0,546>r_{\text {tabel }}=0,349$ dan $\left.t_{\text {hitung }}=3,505>t_{\text {tabel }}=1,696.3\right)$ Terdapat hubungan yang positif dan berarti antara Minat Belajar dan Pengetahuan Menggambar Teknik dengan hasil belajar Menggambar Dengan Perangkat Lunak dengan besar diperoleh $R_{Y(1,2)}=0,502>r_{\text {tabel }}=0,349$ dan uji keberartian korelasi dengan menggunakan Uji-F diperoleh $F_{\text {hitung }}=4,846>F_{\text {tabel }}=3,333$. Dengan demikian Minat Belajar dan Pengetahuan Menggambar Teknik mempunyai hubungan yang positif dan berarti dengan hasil belajar Menggambar Dengan Perangkat Lunak.
\end{abstract}

\section{Kata Kunci : Minat Belajar, Pengetahuan Menggambar Teknik, Hasil Belajar}




\section{PENDAHULUAN}

Pendidikan merupakan salah satu wujud kebudayaan manusia, dimana kebudayaan itu sendiri tumbuh dan berkembang mengikuti dinamika perkembangan zaman. Dengan demikian perkembangan dan perubahan sistem pendidikan, kurikulum, dan komponen pendidikan lainnya merupakan hal yang wajar terjadi dalam dunia pendidikan. Penyempurnaan sistem pendidikan dan komponen lainnya perlu dilakukan terus menerus dan sistematik, selain untuk menyesuaikan dunia pendidikan dengan kebutuhan dan perkembangan ilmu dan teknologi dalam masyarakat, juga untuk menjawab tantangan masa depan.

Pada masa sekarang ini, perkembangan zaman menuntut manusia untuk dapat bertahan mengikuti perkembangan Era Globalisasi. Ilmu pengetahuan sebagai salah satu benteng pertahanan mutlak harus dimiliki setiap individu, karena dengan adanya ilmu pengetahuan manusia akan mampu bersaing dengan manusia lainnya. Pendidikan sebagai salah satu proses memperoleh ilmu pengetahuan sudah selayaknya bisa menjadi wadah untuk memperkaya diri dengan sumber daya yang mampu menempatkan setiap individu pada tingkatan tertinggi dalam kehidupannya.

Pendidikan kejuruan merupakan pendidikan menengah yang mempersiapkan peserta didik terutama dalam pekerjaan tertentu. Schippers dan Ratriana (1994:1) menyatakan tujuan pendidikan kejuruan adalah membekali siswa agar memiliki kompetensi perilaku dalam bidang kejuruan tertentu sehingga mampu bekerja demi masa depan dan untuk kesejahteraan bangsa.

SMK Negeri 1 Lubuk Pakam merupakan salah satu lembaga pendidikan formal yang memberi bekal pengetahuan, teknologi, keterampilan, sikap mandiri, disiplin, serta etos kerja yang terampil dan kreatif sehingga kelak menjadi tenaga kerja yang memiliki pengetahuan dan keterampilan tingkat menengah yang sesuai dengan bidangnya.

Sesuai dengan tujuan SMK di atas, maka lulusan SMK Program Keahlian Teknik Gambar Bangunan diharapkan dapat menguasai mata diklat Menggambar Dengan Perangkat Lunak baik secara teori maupun prakteknya sehingga dapat bersaing dan memperoleh pekerjaan sesuai dengan bidangnya.

Berdasarkan pengamatan penulis melalui observasi awal yang dilakukan di SMK Negeri 1 Lubuk Pakam pada siswa kelas XI Program Keahlian Teknik Gambar Bangunan, ditemukan bahwa hasil belajar yang diperoleh siswa pada mata pelajaran Menggambar Dengan Perangkat Lunak cenderung kurang memuaskan. Hal ini dapat dilihat dari Daftar Kumpulan Nilai (DKN), peneliti menemukan bahwa hasil belajar siswa kelas XI Program Keahlian Teknik Gambar Bangunan SMK Negeri 1 Lubuk Pakam Tahun Ajaran 2012/2013 pada semester ganjil bahwa dari 30 siswa, yang memperoleh nilai 70-79 sebanyak 29 siswa, memperoleh nilai 80-89 sebanyak 1 siswa dan memperoleh nilai 90100 tidak ada, dengan Kriteria Ketuntasan Minimum (KKM) yang berlaku di SMK Negeri 1 Lubuk Pakam tersebut sebesar 70. Dari data ini dapat dilihat bahwa nilai rata-rata Menggambar Dengan Perangkat Lunak perlu peningkatan dan dapat dikatakan hanya cukup memenuhi standart kelulusan saja yaitu 70 .

Dari data di atas dapat dijelaskan bahwa hasil belajar Menggambar Dengan Perangkat Lunak belum optimal dan perlu ditingkatkan. Standar optimal yang dimaksudkan, meskipun nilai 70 merupakan nilai minimal KKM, namun hasil belajar siswa dikatakan optimal jika kemampuan siswa dalam menggambar seharusnya mencapai kategori baik (nilai B). Untuk mengatasi hal tersebut maka diperlukan upaya guru untuk meningkatkan hasil belajar siswa.

Untuk mengatasi masalah tersebut maka diperlukan upaya guru untuk meningkatkan hasil belajar siswa. Salah satu upaya yang dapat dilakukan adalah dengan menumbuhkan minat belajar dalam diri siswa. Slameto (2003 : 180) menyatakan bahwa minat adalah suatu rasa yang lebih suka dan rasa ketertarikan pada suatu hal atau aktivitas, tanpa ada yang menyuruh.

Minat merupakan faktor psikologis yang terdapat pada setiap orang. Sehingga minat terhadap sesuatu/kegiatan tertentu dapat dimiliki setiap orang. Seseorang yang menaruh minat pada satu pelajaran biasanya cenderung memberi perhatianya dengan baik.

Keberhasilan suatu pendidikan, khususnya SMK tidak terlepas dari pengetahuan siswa dalam menggambar teknik. Pengetahuan menggambar teknik yaitu 
pengetahuan siswa untuk membuat gambar kerja pada bidang kertas dengan menggunakan skala tertentu dan gambar tersebut dapat menyampaikan informasi yang ingin disampaikan oleh si perencana. Dalam hal ini minat dan pengetahuan menggambar teknik merupakan pendorong bagi siswa untuk belajar lebih giat agar memperoleh hasil belajar yang optimal.

Dari kedua faktor di atas, faktor hasil belajar seorang siswa juga mempengaruhi tujuan pembelajaran dapat tercapai. Menurut pernyataan Sudjana (1998:28) bahwa hasil belajar adalah penilaian dari hasil usaha/kegiatan yang dinyatakan dalam bentuk angka atau huruf yang dapat mencerminkan hasil yang dicapai oleh seseorang dalam jangka waktu tertentu. Sehingga dapat dikatakan bahwa hasil Menggambar Dengan Perangkat Lunak adalah suatu penilaian atas usaha dan kemampuan yang dicapai oleh siswa dalam memahami dan mengekpresikan ide-ide ke dalam gambar melalui dasar-dasar bidang ilmu Menggambar Dengan Perangkat Lunak yang dalam hal ini diukur dengan menggunakan tes hasil belajar.

Hasil belajar merupakan gambaran tingkat penguasaan terhadap sesuatu yang diperoleh dalam proses belajar setelah dilakukan evaluasi. Hal belajar ini dipengaruhi oleh pengusaan teoritis (kognitif), sikap (afektif) dan keterampilan (psikomotorik) dari setiap bidang ilmu serta aktivitas belajar yang dilakukan individu. Hasil belajar Menggambar Dengan Perangkat Lunak adalah pengusaan teoritis, sikap dan keterampilan Menggambar Dengan Perangkat Lunak.

Berdasarkan uraian di atas, maka penulis tertarik untuk melakukan penelitian dan mengangkatnya dalam sebuah skripsi dengan judul : "Hubungan Minat Belajar dan Pengetahuan Menggambar Teknik dengan Hasil Belajar Menggambar Dengan Perangkat Lunak pada Siswa Kelas XI Program Keahlian Teknik Gambar Bangunan SMK Negeri 1 Lubuk Pakam Tahun Ajaran 2014/2015."

\section{A. Tujuan Penelitian}

Tujuan penelitian ini adalah untuk mengetahui

1. Hubungan Minat Belajar dengan hasil belajar Menggambar Dengan Perangkat Lunak siswa kelas XI Program Keahlian Teknik Gambar Bangunan SMK Negeri 1 Lubuk Pakam Tahun Pelajaran 2014/2015.
2. Hubungan Pengetahuan Menggambar Teknik dengan hasil belajar Menggambar Dengan Perangkat Lunak siswa kelas XI Program Keahlian Teknik Gambar Bangunan SMK Negeri 1 Lubuk Pakam Tahun Pelajaran 2014/2015.

3. Hubungan Minat Belajar dan Pengetahuan Menggambar Teknik dengan hasil belajar Menggambar Dengan Perangkat Lunak siswa kelas XI Program Keahlian Teknik Gambar Bangunan SMK Negeri 1 Lubuk Pakam Tahun Pelajaran 2014/2015.

\section{B. Manfaat Penelitian}

Dengan tercapainya tujuan penelitian di atas, maka diharapkan hasil penelitian ini bermanfaat :

1. Memberikan informasi tentang hubungan Minat Belajar dan Pengetahuan Menggambar Teknik dengan hasil belajar Menggambar Dengan Perangkat Lunak siswa kelas XI Program Keahlian Teknik Gambar Bangunan SMK Negeri 1 Lubuk Pakam Tahun Pelajaran 2014/2015.

2. Sebagai bahan masukan bagi para guru mata pelajaran Menggambar Dengan Perangkat Lunak khususnya guru di SMK Negeri 1 Lubuk Pakam untuk peningkatan hasil belajar Menggambar Dengan Perangkat Lunak siswa.

3. Sebagai bahan masukan bagi lembaga SMK khususnya Sekolah Menengah Kejuruan Negeri 1 Lubuk Pakam tentang arti pentingnya Minat Belajar dan Pengetahuan Menggambar Teknik dalam meningkatkan kualitas lulusannya.

4. Sebagai bahan studi banding bagi penelitian-penelitian yang relevan dikemudian hari dengan melibatkan variabel yang lebih kompleks.

\section{KERANGKA TEORITIS, KERANGKA KOSEPTUAL, DAN PENGAJUAN HIPOTESIS}

A. Keranggka Teoritis

1. Hakikat Minat Belajar

a. Pengertian Minat Belajar

Dalam Kamus Besar Bahasa Indonesia (KBBI), minat berarti kecenderungan hati yang tinggi terhadap sesuatu, diartikan pula sebagai gairah atau keinginan. Dalam bahasa inggris, minat sering digambarkan dengan kata-kata "Interest" atau "Passion". "Interest" bermakna suatu perasaan ingin memerhatikan dan penasaran akan sesuatu hal, sedangkan "Passion" sama maknanya dengan 
gairah atau suatu perasaan yang kuat atau antusiasme terhadap suatu objek. Ada juga yang menyebutnya sebagai "Proclivity" yang berarti kecenderungan atau kehendak hati.

Menurut Joko Sudarsono (2003:8), “ Minat merupakan bentuk sikap ketertarikan atau sepenuhnya terlibat dengan suatu kegiatan karena menyadari pentingnya atau bernilainya kegiatan tersebut". Defenisi secara sederhana lainya diberikan oleh Muhibbin Syah (2008:136) yang mendefinisikan bahwa " minat (interest) berarti kecenderungan dan kegairahan yang tinggi atau keinginan yang besar terhadap sesuatu".

Menurut Slameto (2010 : 180), minat adalah suatu rasa lebih suka dan rasa keterikatan pada suatu hal atau aktivitas, tanpa ada yang menyuruh. Minat pada dasarnya adalah penerimaan akan suatu hubungan antara diri sendiri dengan sesuatu di luar diri. Semakin kuat atau dekat hubungan tersebut, semakin besar minat. Hillgard dalam Slameto (2010:57) memberikan rumusan tentang minat sebagai berikut " interest is persisting to pay attention to and enjoy some activity or content", yang berarti bahwa minat adalah kecenderungan yang tetap untuk memperhatikan dan mengenang beberapa kegiatan.

Dari pemaparan para ahli di atas, dapat ditarik kesimpulan bahwa minat merupakan suatu hasrat atau keinginan yang ada dalam diri individu terhadap sesuatu yang disukainya. Minat juga merupakan perasaan senang yang timbul dalam diri seseorang, Pemusatan tenaga fisik yang tertuju kepada suatu objek dan merupakan besar kecilnya kekuatan yang menyertai aktivitas.

Suatu minat dapat diekspresikan melalui suatu pernyataan yang menunjukan bahwa siswa lebih menyukai suatu hal daripada hal lainnya, dapat pula dimanifestasikan melalui partisipasi dalam suatu aktivitas. Siswa yang memiliki minat terhadap subyek tertentu cenderung untuk memberikan perhatian yang lebih besar terhadap subyek tersebut. Minat tidak dibawa sejak lahir, melainkan diperoleh kemudian. Minat terhadap sesuatu dipelajari dan mempengaruhi belajar selanjutnya serta mempengaruhi penerimaan minat-minat baru. Jadi minat terhadap sesuatu merupakan hasil belajar dan menyokong belajar selanjutnya. Walupun minat terhadap sesuatu hal tidak merupakan hal yang hakiki untuk dapat mempelajari hal tersebut, asumsi umum menyatakan bahwa minat akan membantu seseorang mempelajarinya.

Mengembangkan minat terhadap sesuatu pada dasarnya adalah membantu siswa melihat bagaimana hubungan antara materi yang diharapkan untuk dipelajari dengan dirinya sendiri sebagai individu. Proses ini berarti menunjukan pada siswa bagaiamana pengetahuan atau kecakapan tertentu mempengaruhi dirinya, melayani tujuantujuanya, memuaskan kebutuhan-kebutuhanya. Bila siswa menyadari bahwa belajar merupakan suatu alat untuk mencapai beberapa tujuan yang dianggapnya penting, dan bila siswa melihat bahwa hasil dari pengalaman belajarnya akan membawa kemajuan pada dirinya, kemungkinan besar ia akan berminat (dan bermotivasi) untuk mempelajarinya.

Tanpa adanya minat dalam diri siswa terhadap hal yang akan dipelajari, maka ia akan ragu-ragu untuk belajar sehingga tidak akan menghasilkan hasil belajar yang baik seperti yang diharapkan. Dalam hal pembelajaran menggambar teknik apabila seseorang tidak mempunyai minat terhadap pelajaran tersebut maka tidak akan suka untuk menggambar, sehingga gambar yang dihasilkan akan terkesan asal-asalan yang tentunya tidak akan memenuhi tuntutan kerja industri.

\section{b. Indikator minat dalam belajar}

Haspah (2008:35), menyatakan bahwa indikator untuk menentukan Minat Belajar seseorang dapat dilihat pada lima aspek yaitu: 1) Rajin dalam belajar, 2) Tekun dalam belajar 3) Rajin dalam mengerjakan tugas, 4) Memiliki jadwal belajar, dan 5) Disiplin dalam belajar. Berikut ini akan dijelaskan masingmasing indikator Minat Belajar tersebut secara singkat.

1) Rajin dalam belajar

Menurut Kridalaksana bahwa : "Rajin adalah berusaha dengan giat dalam mencapai sesuatu". Ahli lain menyatakan bahwa: "Rajin adalah seseorang yang suka bekerja keras dan terus menerus". Dari pendapat kedua ahli di atas dapat ditarik kesimpulan bahwa rajin adalah orang yang rajin berusaha secara terusmenerus untuk mencapai sesuatu di dalam belajarnya.

2) Tekun dalam belajar

Dalam buku Psikologi Pendidikan dijelaskan bahwa: "Tekun adalah seseorang yang sungguh-sungguh dalam belajar". Ahli 
lain menyatakan bahwa: "Ketekunan adalah orang yang betul-betul berkeras hati dalam mengerjakan sesuatu yang menjadi tujuanya". Dari pendaapt para ahli di atas, maka yang dimaksud dengan tekun adalah seseorang yang sungguh-sungguh dan berkeras hati dalam mengerjakan sesuatu yang menjadi tujuanya.

3) Rapi dalam mengerjakan tugas

Menurut Sunartana: "Rapi adalah bersih ataupun teratur dalam mengerjakannya". Ahli lain menyatakan bahwa: "Rapi adalah baik, teratur, bersih dalam mengerjakan sesuatu yang menjadi tanggung jawab". Dari pendapat para ahli di atas, maka yang dimaksud dengan rapi adalah dalam mengerjakan tugas siswa harus memperhatikan keteraturan dan kebersihan gambar yang diberikan.

4) Memiliki jadwal belajar

Jadwal belajar adalah: “ jadwal pembagian jadwal belajar". Yang dimaksud dengan jadwal belajar adalah siswa memiliki pembagian waktu belajar berdasarkan urutan pelajaran di sekolahnya masing-masing maupun di rumah.

5) Disiplin dalam belajar

Dalam buku Pemahaman Individu 1 dijelaskan bahwa: "Disiplin adalah kepatuhan di dalam menaati peraturan yang ada". Ahli lain menyatakan bahwa: "Disiplin adalah kepatuhan di dalam mengikuti aturan-aturan didalam belajar". Dari pendapat ahli tersebut, maka yang dimaksud dengan disiplin dalam belajar adalah ketaatan dan kepatuhan siswa di dalam mengikuti aturan belajar khususnya dalam bidang mekanikal di sekolah ataupun di luar sekolah.

Menurut pengertian secara biologis, belajar merupakan suatu proses perubahan yaitu perubahan tingkah laku sebagai hasil dari interaksi dengan lingkunganya dalam memenuhi kebutuhan hidupnya. Perubahanperubahan tersebut akan nyata pada seluruh aspek tingkah laku.

Dalam bagian lain Slameto (2010) menjelaskan bahwa belajar adalah suatu proses usaha yang dilakukan seseorang untuk memperoleh suatu perubahan tingkah laku yang baru secara keseluruhan, sebagai hasil pengalamanya sendiri dalam interaksi dengan lingkungannya.

Dalam kegiatan belajar, minat merupakan salah satu faktor psikologis yang memungkinkan terjadinya dorongan dan konsentrasi belajar. Menyadari hal itu maka guru dalam proses belajar harus mempunyai kemampuan tidak hanya membekali diri dengan materi saja tetapi juga harus mengetahui bagaimana menyampaikan pelajaran agar menarik perhatian siswa, sehingga apa yang menjadi tujuan dari pengajaran tersebut dapat tercapai.

Dengan demikian dapat disimpulkan bahwa Minat Belajar adalah keinginan dalam diri seseorang untuk mempelajari suatu objek yang didorong oleh rasa ingin tahu untuk mencapi tujuanya. Dengan indikator: 1) rajin dalam belajar, 2) tekun dalam belajar, 3) rapi dalam mengerjakan tugas, 4) memiliki jadwal belajar, 5) disiplin dalam belajar.

\section{Hakikat Pengetahuan Menggambar Teknik}

Pengetahuan yang dimiliki seseorang merupakan suatu kemahiran tersendiri yang dimilikinya dan tingkat pengetahuan seseorang berbeda-beda. Orang yang memiliki tingkat pengetahuan yang tinggi akan mampu mengontrol dan menyalurkan aktivitas pengetahuan yang berlangsung dalam dirinya. Pengetahuan seseorang dipengaruhi oleh beberapa faktor atau aspek antara lain faktor pembawaan, faktor lingkungan, faktor kematangan, dan faktor kebebasan. Jika seseorang dapat menyelesaikan pekerjaan dengan hasil baik dalam waktu yang singkat maka orang tersebut dapat dikatakan memiliki tingkat pengetahuan yang tinggi.

Menurut Bloom (1956) mengemukakan ada tiga ranah atau domain besar yang selanjutnya disebut taksonomi salah satunya adalah pengetahuan. Kemudian ranah pengetahuan tersebut dibagi menjadi enam bagian yaitu mengenal, pemahaman, penerapan atau aplikasi, analisis, sintesis, dan evaluasi.

Pendekatan pengetahuan (kognitif) pada hakekatnya bekaitan erat dengan peningkatan tingkat intelektual setiap individu. Menurut Natawidjaya (1984:132) menyatakan bahwa hakekat gaya kognitif bersangkutan dengan daya pikir, pengetahuan, dan penalaran. Hal ini sejalan dengan pendapat Rahman (1999:169) yang menyatakan hakekat kognitif mencakup aspek-aspek struktur intelek yang dipergunakan untuk mengetahui sesuatu.

Purwanto (2006) mengemukakan bahwa menggambar teknik adalah gambar yang dibuat dengan menggunakan cara-cara, ketentuan-ketentuan, dan aturan-aturan yang telah disepakati oleh ahli-ahli teknik. 
Kemudian Luzzader (2003) menyatakan bahwa gambar teknik merupakan suatu sarana yang terpenting untuk melukiskan daya cipta lewat penggunaan garis. Gambar merupakan sarana penyampaian informasi yang berfungsi sebagai alat untuk meneruskan maksud dari si perencana dengan tepat kepada orang-orang yang bersangkutan.

Selanjutnya menurut Sugiarto (1990:1) menyatakan "penerusan informasi adalah fungsi yang penting untuk bahasa maupun gambar". Oleh karena itu diharapkan bahwa gambar harus meneruskan keteranganketerangan secara tepat objektif. Hal ini sejalan dengan pendapat Mukomoko (1996:1) bahwa menggambar teknik bangunan adalah gambar yang menjelaskan bentuk bangunan secara jelas serta skala dan ukurannya dari bangunan itu sendiri sehingga para pelaksana mengerti.

Menurut Siregar (2010:1) menggambar teknik dimaksudkan untuk setiap menggambar atau melukiskan benda yang disertai dengan ukuran-ukuran tiap perubahan bentuk gambar atau lukisan tersebut menurut aturan-aturan dan normalisasi teknik. Gambar benda yang dilukiskan menurut gambar teknik biasanya ditujukan untuk membuat (memprodusir) benda tersebut di dalam operasi yang bersifat teknis dan ekonomis. Menggambar Teknik (Drafting Technology) lebih dianggap sebagai perancangan suatu produk teknologi (satuan operasi) dalam proses operasi.

Dalam bukunya Siregar (2010 : 6) menyatakan term gambar teknik (engineering graphics) mencakup bidang yang sangat luas yang menggunakan gambar untuk menjawab berbagai persoalan dan memperlihatkan suatu jawaban. Gambar teknik terbagi atas 3 (tiga) bagian utama yaitu: gambar kerja (working drawings), deskripsi geometris (descriptive geometry), dan bidang khusus (special area)

Dari uraian di atas dapat disimpulkan bahwa Pengetahuan Menggambar Teknik adalah tingkat kesanggupan siswa dalam memecahkan masalah dan penalaran yang dimilikinya khususnya sesuatu yang berhubungan dengan gambar teknik.

Pada mata diklat menerapkan dasar-dasar gambar teknik memiliki kompetensi dasar yang harus dimiliki siswa, dengan indikator yaitu, a) Mengidentifikasi peralatan menggambar teknik, b) Macam-macam garis dan penggunaannya, c) Bentuk ukuran dan penggunaan huruf, d) Menggambar proyeksi.

\section{Hakikat Hasil Belajar Menggambar dengan Perangkat Lunak}

Hasil belajar terdiri dari dua kata, yaitu "hasil" dan "belajar". Hasil adalah akibat yang timbul karena berlangsungnya suatu proses kegiatan, dan belajar adalah dalam interaksi dengan lingkungan.

Menurut Nana Sudjana (dalam Kunandar, 2008) hasil belajar adalah suatu akibat dari proses pembelajaran dengan menggunakan alat pengukur, yaitu berupa tes yang disusun secara terencana, baik tes tertulis, tes lisan, maupun tes perbuatan. S. Nasution (dalam Kunandar, 2008) berpendapat bahwa hasil belajar adalah suatu perubahan pada individu yaitu belajar. Tidak hanya mengenai pengetahuan, tetapi juga membentuk kecakapan dan penghayatan dalam diri individu yang belajar.

Hasil belajar pada dasarnya merupakan hasil interaksi dari berbagai faktor yang mempengaruhi proses belajar secara keseluruhan. Hasil interaksi menimbulkan adanya perbedaan hasil belajar dan menghasilkan adanya pengelompokkan individu tertentu. Sudjana (2005:22) mengemukakan bahwa hasil belajar adalah kemampuan-kemampuan yang dimiliki setelah ia menerima pengalaman hidupnya.

Jadi dapat dibuat kesimpulan bahwa hasil belajar siswa diukur dari 1) ranah kognitif yaitu kemampuan dalam mengingat materi yang dipelajari dan kemampuan mengembangkan intelegensi, 2) ranah afektif yaitu kemampuan yang berhubungan dengan sikap kejiwaan seperti kecenderungan akan minat dan motivasi, 3) ranah psikomotorik yaitu kemampuan yang berhubungan dengan keterampilan atau skill yang berkaitan dengan fisik.

Menurut Soma (2002:1) AutoCAD memiliki fasilitas yang sangat komplit untuk menggambar dua dimensi dan tiga dimensi. Selanjutnya menurut Soma (2002:5) juga AutoCAD secara lebih konseptual dan dapat membuat gambar dua dimensi apapun dengan tempo yang lebih cepat, akurat, dan sempurna dibandingkan dengan menggambar manual, sehingga mampu menghasilkan gambar yang lebih profesional. Sesuai dengan pendapat di atas dapat disimpulkan bahwa AutoCAD adalah program aplikasi berbasis grafik yang dimaksudkan untuk membantu dan mempermudah pembuatan gambar 2D dan 3D atau gambar arsitektur (rancang bangun). 
Berdasarkan pernyataan di atas, dapat dijelaskan bahwa hasil belajar Menggambar Dengan Perangkat Lunak dapat menghasilkan siswa yang lebih terampil dan kreatif dalam mendesain dengan menggunakan program komputer AutoCAD.

\section{B. Kerangka Konseptual}

Sesuai dengan judul yang dirumuskan oleh peneliti dijelaskan beberapa hal untuk mensejajarkan pengertian akan hal yang dimaksudkan dalam penelitiannya, antara lain adalah:

\section{Hubungan Minat Belajar dengan Hasil Belajar Menggambar Dengan Perangkat Lunak}

Minat Belajar adalah suatu perasaan atau sikap tertarik siswa dalam melakukan aktivitas yang cenderung menetap tetapi minat itu boleh berkurang tapi tidak akan terlupakan. Apabila seseorang lama tidak melakukan aktivitas yang diminatinya tidak bermakna ia melupakan sama sekali aktivitas tersebut, minat tersebut akan diingatnya dengan jelas kembali apabila ia kembali melakukan aktivitas tersebut. Jika seseorang siswa tersebut berminat dalam pelajaran menggambar maka hasil belajarnya dalam menggambar akan meningkat, begitu juga sebaliknya jika Minat Belajarnya kurang maka hasil belajarnya akan kurang baik.

Minat adalah suatu landasan yang paling menyakinkan demi keberhasilan suatu proses belajar. Untuk itu dalam proses belajar hendaknya siswa benar-benar menaruh minat terhadap pelajaran yang diikuti, sebab suatu pelajaran dapat dipelajari dengan baik apabila ada pemusatan, konsentrasi, atau perhatian terhadap pelajaran yang diikuti. Jika minat siswa ada, ini akan mendorong siswa itu untuk berusaha lebih giat dalam belajar. Guru juga harus memberikan perhatian kepada siswa agar minat untuk belajarnya berlanjut untuk meningkatkan hasil belajarnya.

Minat yang lahir dari rasa suka dan senang akan menimbulkan satu ketertarikan pada suatu hal atau aktivitas, tanpa ada yang menyuruh. Menurut peneliti belajar yang datangnya dari diri sendiri tanpa ada yang menyuruh ini akan mendorong keinginan siswa tersebut untuk lebih giat belajar khususnya dalam Menggambar Dengan Perangkat Lunak yang pada akhirnya akan meningkatkan hasil belajar siswa tersebut.

\section{Hubungan Pengetahuan Menggambar Teknik dengan Hasil Belajar}

\section{Menggambar Dengan Perangkat \\ Lunak}

Pengetahuan Menggambar Teknik merupakan satu faktor yang mempengaruhi hasil belajar yang dilakukan siswa tanpa adanya paksaan dari orang lain untuk mendapatkan dan menguasai sesuatu. Hal ini juga dinyatakan dalam Kamus Besar Bahasa Indonesia, pengetahuan adalah kecekapan dalam melakukan tugas. Hasil belajar yang ingin dicapai haruslah hasil belajar yang maksimal. Karena hasil belajar yang maksimal merupakan jalan yang dapat memudahkan proses kelanjutan studi dan pencapaian citacita. Akan tetapi semua itu tidaklah mudah, karena aktivitas belajar pada tiap siswa berbeda-beda.I

Oleh karenanya di SMK, siswa diberi pelajaran Menggambar Dengan Perangkat Lunak yang mengunakan program komputer AutoCAD agar dapat meningkatkan kemampuan dan mahir dengan dunia IPTEK. Materi AutoCAD adalah sebuah materi yang membahas cara penggunaan menggambar dengan menggunakan kaedah berkomputer. Hasil usaha dalam AutoCAD mengalami perkembangan yang sangat fenomenal dan mempunyai andil besar dalam perkembangan industry manufacturing dewasa ini yang merupakan kualitas pencapaian dalam tujuan belajar. Kompatibilitasnya yang tinggi memungkinkan gambar-gambar AutoCAD dapat diterima oleh sebagian besar program menggambar lain dan dapat dicetak dengan menggunakan hampir semua alat pencetak. Untuk mendapatkan hasil gambar yang baik seseorang individu harus mempunyai pengetahuan dalam menggambar dan penggunaan AutoCAD.

Dengan demikian dapat disimpulkan bahwa semakin tinggi Pengetahuan Menggambar Teknik siswa akan memberi hubungan yang berarti terhadap hasil belajar Menggambar Dengan Perangkat Lunak siswa dengan baik dan cemerlang.

\section{Hubungan Minat Belajar dan Pengetahuan Menggambar Teknik dengan Hasil Belajar Menggambar Dengan Perangkat Lunak}

Hasil belajar merupakan hasil yang diperoleh siswa ketika mengikuti dan mengerjakan tugas dan kegiatan belajar di sekolah atau hasil yang telah dicapai siswa dalam proses dan usaha belajarnya. Hasil belajar Menggambar Dengan Perangkat Lunak 
adalah hasil yang dicapai siswa ketika mengikuti dan mengerjakan tugas dan kegiatan belajar di sekolah melalui program komputer AutoCAD.

Dengan demikian, Minat Belajar yang ada ditambah dengan Pengetahuan Menggambar Teknik dan pengembangan jawaban yang banyak dalam suatu persoalan dalam menggambar teknik diharapkan mempunyai pengetahuan dasar dalam menggambar dengan menggunakan program AutoCAD serta sesuai dengan apa yang diharapkan, karena menggambar teknik dengan alat tulis yang baik diharapkan Menggambar Dengan Perangkat Lunak AutoCAD juga semakin baik.

Dalam hal ini Minat Belajar dan Pengetahuan Menggambar Teknik merupakan pendorong bagi siswa untuk belajar lebih giat agar dapat memperoleh hasil belajar yang optimal. Minat Belajar dan Pengetahuan Menggambar Teknik pada siswa diharapkan mendukung hasil belajar siswa. Minat Belajar dan Pengetahuan Menggambar Teknik siswa merupakan faktor dalam usaha meningkatkan dan memperoleh hasil belajar yang baik seperti yang diinginkan oleh lembaga pendidikan.

\section{Pengajuan Hipotesis}

Berdasarkan kerangka teoritis dan kerangka konseptual, maka hipotesis dalam penelitian ini dapat diajukan sebagai berikut :

1. Terdapat hubungan yang positif dan berarti antara Minat Belajar dengan hasil belajar Menggambar Dengan Perangkat Lunak pada siswa kelas XI Program Keahlian Teknik Gambar Bangunan SMK Negeri 1 Lubuk Pakam Tahun Ajaran 2014/2105.

2. Terdapat hubungan yang positif dan berarti antara Pengetahuan Menggambar Teknik dengan hasil belajar Menggambar Dengan Perangkat Lunak pada siswa kelas XI Program Keahlian Teknik Gambar Bangunan SMK Negeri 1 Lubuk Pakam Tahun Ajaran 2014/2105.

3. Terdapat hubungan yang positif dan berarti antara Minat Belajar dan Pengetahuan Menggambar Teknik dengan hasil belajar Menggambar Dengan Perangkat Lunak pada siswa kelas XI Program Keahlian Teknik Gambar Bangunan SMK Negeri 1 Lubuk Pakam Tahun Ajaran 2014/2105.

\section{METODOLOGI PENELITIAN}

\section{A. Tempat dan Waktu Penelitian}

Tempat penelitian ini dilakukan di SMK Negeri 1 Lubuk Pakam Jl. Galang Lubuk Pakam pada siswa kelas XI Program Keahlian Teknik Gambar Bangunan pada Tahun Ajaran 2014/2015. Pengumpulan data dilakukan pada bulan Januari 2015.

\section{B. Populasi dan Sampel Penelitian \\ 1. Populasi Penelitian}

Populasi penelitian ini adalah seluruh siswa tingkat XI Program Keahlian Teknik Gambar Bangunan Tahun Ajaran 2014/2015 yang terdiri dari 2 kelas yaitu kelas A dan kelas B yang berjumlah 60 orang.

\section{Sampel Penelitian}

Sampel adalah bagian dari jumlah dan karakteristik yang dimiliki oleh populasi. Sejalan dengan pendapat tersebut, Arikunto (2010:174) menyatakan sampel adalah sebagian atau wakil dari populasi yang diteliti. Dalam hal ini peneliti menetapkan sampel penelitian dengan menggunakan metode Purposive Sampling yaitu teknik pengambilan sampel secara sengaja karena adanya pertimbangan/ syarat-syarat tertentu yaitu melihat sifat dan karakteristik siswa yang cenderung homogen, jumlah siswa relatif sama, maka peneliti menetapkan jumlah sampel dalam penelitian ini adalah 32 orang yakni kelas XI A Program Keahlian Teknik Gambar Bangunan.

\section{Metode Penelitian}

Sesuai dengan tujuan penelitian ini, yaitu untuk mengetahui hubungan antara Minat Belajar dan Pengetahuan Menggambar Teknik dengan hasil belajar Menggambar Dengan Perangkat Lunak, maka metode penelitian ini adalah Metode Deskriptif Korelasional, yaitu suatu metode penelitian yang bertujuan untuk memperoleh informasi tentang suatu gejala pada saat penelitian dilakukan, dengan paradigma sebagai berikut:

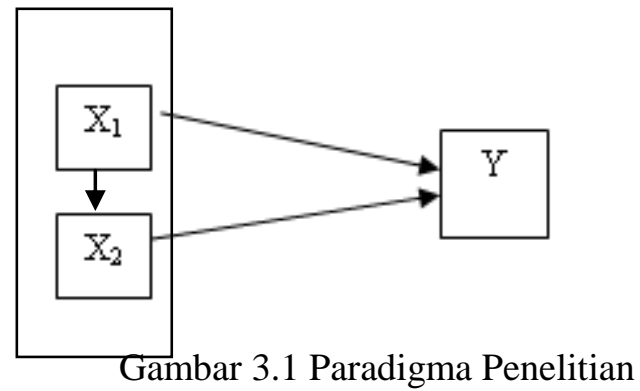

Keterangan: 
$\mathrm{X}_{1}=$ Minat Belajar

$\mathrm{X}_{2}=$ Pengetahuan Menggambar Teknik

$\mathrm{Y}=$ Hasil Belajar Menggambar Dengan

Perangkat Lunak

\section{Definisi Operasional}

Penelitian ini menggunakan tiga variabel, yaitu Hasil Belajar Menggambar Dengan Perangkat Lunak (Y) sebagai variabel terikat,Minat Belajar $\left(\mathrm{X}_{1}\right)$, dan Pengetahuan Menggambar Teknik $\left(\mathrm{X}_{2}\right)$ sebagai variabel bebas. Untuk mengukur variabel secara kuantitatif perlu dilakukan definisi operasional, sebagai berikut:

\section{Variabel Terikat}

Variabel terikat adalah kondisi atau karakteristik yang berubah atau muncul sehubungan dengan pelaksanaan pemilihan ketika mengintroduksi atau mengganti variabel bebas. Adapun variabel terikat dalam penelitian ini adalah Hasil Belajar Menggambar Dengan Perangkat Lunak siswa.

Hasil belajar Menggambar Dengan Perangkat Lunak adalah hasil usaha dan kemampuan yang diperoleh siswa melalui proses belajar pada program diklat Menggambar Dengan Perangkat Lunak yang dinyatakan dalam bentuk angka atau huruf yang diukur melalui tes pada subjek didik.

\section{Variabel Bebas}

Variabel bebas adalah kondisi atau karakteristik yang dimanipulasi untuk merangkap hubungannya dengan gejala yang diobservasikan atau dengan kata lain variabel bebas itu disebut juga dengan gejala yang mempengaruhi suatu gejala. Variabel bebas dalam penelitian ini adalah :

a. Minat belajar $\left(\mathrm{X}_{1}\right)$

Minat belajar adalah sesuatu yang pribadi dalam diri siswa berupa adanya perhatian, keinginan, perasaan senang, dan adanya kesiapan mental untuk meningkatkan kemampuan serta hasil belajar Menggambar Dengan Perangkat Lunak melalui media komputer dengan penggunaan software AutoCAD.

b. Pengetahuan Menggambar Teknik $\left(\mathrm{X}_{2}\right)$

Pengetahuan Menggambar Teknik adalah gambaran kemampuan atau kesanggupan memahami dan menguasai materi menggambar teknik pada kompetensi mengenal alat-alat gambar, penggunaan jenisjenis garis, penggunaan bentuk dan ukuran huruf, dan menggambar proyeksi.

\section{E. Teknik Pengumpulan Data}

1. Instrumen Minat Belajar
Instrumen Minat Belajar siswa dijaring dengan menggunakan angket/kuisioner. Penggunaan angket ini didasarkan pada pendapat Hadjar (1996) yang mengatakan bahwa: 1) Bentuk ini cocok bila penelitian lebih menekankan pada respon kelompok secara umum, 2) Waktu yang dibutuhkan untuk meresponnya relatif singkat, 3) Membentuk subjek dalam menafsirkan butir yang diajukan sehingga mengurangi salah tafsir, dan 4) Lebih mudah dalam penskoran hasilnya dan lebih efisien.

Penggunaan angket ini terdiri dari empat jawaban yang merentang dari "Sangat Setuju" sampai pada "Sangat Tidak Setuju". Untuk pernyataan positif diberi bobot sebagai berikut: Sangat Setuju $(\mathrm{SS})=4$, Setuju $(\mathrm{S})=3$, Tidak Setuju $(\mathrm{TS})=2$, dan Sangat Tidak Setuju $($ STS $)=1$. Adapun kisi-kisi angket dari instrumenMinat Belajar siswa dapat dilihat pada Tabel 1 berikut ini:

Tabel 1 Kisi-kisi Angket Minat Belajar Siswa

\begin{tabular}{|c|l|c|c|}
\hline No & \multicolumn{1}{|c|}{ Indikator } & No.Butir Angket & Jumlah \\
\hline 1 & $\begin{array}{l}\text { Rajin dalam } \\
\text { belajar }\end{array}$ & $\begin{array}{c}2,3,10,12,13,20,24, \\
27,30\end{array}$ & 9 \\
\hline 2 & $\begin{array}{l}\text { Tekun dalam } \\
\text { belajar }\end{array}$ & $1,4,6,19,21,26,18$ & 7 \\
\hline 3 & $\begin{array}{l}\text { Rapi dalam } \\
\text { mengerjakan } \\
\text { tugas }\end{array}$ & $9,11,22,28$ & 4 \\
\hline 4 & $\begin{array}{l}\text { Memiliki } \\
\text { jadwal belajar }\end{array}$ & $8,25,5,15,17$ & 5 \\
\hline 5 & $\begin{array}{l}\text { Disiplin } \\
\text { dalam belajar }\end{array}$ & $7,14,23,29,16$ & 5 \\
\hline \multicolumn{2}{|c|}{ Jumlah } & $\mathbf{3 0}$ \\
\hline
\end{tabular}

2. Instrumen Pengetahuan Menggambar Teknik

Data untuk Pengetahuan Menggambar Teknik peneliti menggunakan tes dalam bentuk pilihan berganda. Setiap butir tes pilihan berganda terdiri dari empat pilihan jawaban. Untuk setiap jawaban yang benar diberi nilai 1 (satu) dan jawaban yang salah diberi nilai 0 (nol). Tes ini adalah untuk mengungkap apa yang mampu dilakukan oleh siswa dan seberapa baik ia mampu melakukan tugas atau tes yang diberikan. Adapun kisi-kisi instrumen tes kemampuan menggambar teknik dapat dilihat pada Tabel 2 berikut ini :

Tabel 2 Kisi-Kisi Tes Pengetahuan Menggambar Teknik

\begin{tabular}{|c|l|c|c|c|c|}
\hline $\begin{array}{c}\mathrm{N} \\
\mathrm{o}\end{array}$ & Indikator & $\begin{array}{c}\text { Pengeta } \\
\text { huan } \\
\mathrm{C} 1\end{array}$ & $\begin{array}{c}\text { Pemaha } \\
\text { man } \\
\mathrm{C} 2\end{array}$ & $\begin{array}{c}\text { Penera } \\
\text { pan } \\
\mathrm{C} 3\end{array}$ & $\begin{array}{c}\text { Juml } \\
\text { ah }\end{array}$ \\
\hline 1. & $\begin{array}{l}\text { Macam- } \\
\text { macam } \\
\text { alat } \\
\text { gambar }\end{array}$ & $1,4,9$ & $\begin{array}{c}8,10, \\
17\end{array}$ & $\begin{array}{c}11,13, \\
29\end{array}$ & 9 \\
\hline 2. & $\begin{array}{l}\text { Macam- } \\
\text { macam } \\
\text { garis dan } \\
\text { penggunaa }\end{array}$ & $2,6,24$ & 15,26 & 12,21 & 7 \\
\hline
\end{tabular}




\begin{tabular}{|c|l|c|c|c|c|}
\hline & nnya & & & & \\
\hline 3. & $\begin{array}{l}\text { Bentuk } \\
\text { ukuran } \\
\text { dan } \\
\text { penggunaa } \\
\text { n huruf }\end{array}$ & 5,23 & 14,16 & 25,27 & 6 \\
\hline 4. & $\begin{array}{l}\text { Menggam } \\
\text { bar } \\
\text { proyeksi }\end{array}$ & $3,7,22$ & $\begin{array}{c}18,19, \\
20,\end{array}$ & 28,30 & 8 \\
\hline & Total & $\mathbf{1 2}$ & $\mathbf{1 3}$ & $\mathbf{5}$ & $\mathbf{3 0}$ \\
\hline
\end{tabular}

3. Instrumen Hasil Belajar Menggambar Dengan Perangkat Lunak

Hasil belajar Menggambar Dengan Perangkat Lunak (Y) dijaring dengan menggunakan tes berbentuk objektif test. Penggunaan tes objektif ini didasarkan pada pertimbangan tentang ciri dari kemampuan, objektivitas, penilaian, waktu, keluasan dan keragaman materi pelajaran yang akan ditanyakan serta kemudahan administrasi penilaian (Arikunto, 2006). Setiap butir tes pilihan berganda terdiri dari empat pilihan jawaban. Untuk setiap jawaban yang benar diberi nilai 1 (satu) daan jawaban yang salah diberi nilai 0 (nol). Adapun kisi-kisi instrumen tes hasil belajar MDPL dapat dilihat pada Table 3 berikut ini :

Tabel 3 Kisi-kisi Instrument Tes Hasil Belajar MDPL

\begin{tabular}{|c|c|c|c|c|c|}
\hline \multirow{2}{*}{ No } & \multirow{2}{*}{ Indikator } & \multicolumn{3}{|c|}{ No Item } & \multirow{2}{*}{ Jumlah } \\
\hline & & $\mathrm{C} 1$ & $\mathrm{C} 2$ & C3 & \\
\hline 1 & $\begin{array}{l}\text { Mengenali } \\
\text { perintah, menu, } \\
\text { icon, dan } \\
\text { melengkapi } \\
\text { gambar dengan } \\
\text { arsiran }\end{array}$ & $\begin{array}{c}2,3, \\
16, \\
17, \\
31, \\
32\end{array}$ & $\begin{array}{l}9, \\
11, \\
15, \\
21, \\
23\end{array}$ & $\begin{array}{c}1,8 \\
16 \\
, 30\end{array}$ & 15 \\
\hline 2 & $\begin{array}{l}\text { Membuat } \\
\text { gambar, } \\
\text { melengkapi } \\
\text { dimensi dan } \\
\text { melakukan } \\
\text { editing }\end{array}$ & $\begin{array}{l}7, \\
18, \\
24, \\
27\end{array}$ & $\begin{array}{l}5, \\
13, \\
14, \\
20, \\
22, \\
28, \\
29\end{array}$ & $\begin{array}{c}4,6, \\
10, \\
19, \\
25, \\
26\end{array}$ & 17 \\
\hline & Jum & oal & & & 32 \\
\hline
\end{tabular}

Keterangan:

$\mathrm{C} 1=$ Pengetahuan, $\mathrm{C} 2$ = Pemahaman, dan $\mathrm{C} 3$ = Aplikasi/penerapan

Pengumpulan data untuk hasil belajar juga dilakukan dengan tes perbuatan yaitu tes menggambar denah bangunan sederhana dengan menggunakan program AutoCAD. Adapun format penilaian untuk tes perbuatan dapat dilihat pada Tabel 4 berikut ini:

Tabel 4. Format Penilaian Tes Perbuatan Hasil Belajar

\begin{tabular}{|c|l|c|c|c|}
\hline No & Indikator & Bobot & Perolehan & Ket. \\
\hline 1 & Langkah kerja & 10 & & \\
\hline \multirow{2}{*}{2} & Sikap kerja & & & \\
& a. Penampilan & 10 & & \\
& b. Perilaku Kerja & 10 & & \\
\hline \multirow{4}{*}{3} & Hasil menggambar & & & \\
& a. Garis & 20 & & \\
& b. Skala & 20 & & \\
& c. $\quad$ Ketelitian & 20 & & \\
\hline
\end{tabular}

\begin{tabular}{|c|c|c|l|l|}
\hline 4 & Waktu/kecepatan & 10 & & \\
\hline Jumlah & 100 & & \\
\hline
\end{tabular}

F. Uji Coba Instrumen Penelitian

Uji coba instrumen bertujuan untuk mendapatkan alat ukur yang benar-benar dapat menjaring data yang akurat agar kesimpulan yang diambil sesuai dengan kenyataan. Sebagaimana yang dikatakan Arikunto (2002) bahwa instrumen penelitian adalah alat atau fasilitas yang digunakan oleh peneliti dalam mengumpulkan data agar pekerjaannya lebih mudah, dan hasilnya lebih baik, dalam arti lebih cermat, lengkap, dan sistematis sehingga mudah diolah.

Dalam penelitian ini instrumen yang digunakan untuk mengambil data adalah instrumen berbentuk angket untuk variabelMinat Belajar, instrumen berbentuk tes untuk variabel Pengetahuan Menggambar Teknik, dan hasil belajar Menggambar Dengan Perangkat Lunak menggunakan tes dan tes perbuatan. Maka hal-hal yang akan diuji coba pada instrumen yang berbentuk angket yang akan diuji coba adalah: validitas dan reliabelitas angket. Sedangkan untuk instrumen yang berbentuk tes pilihan berganda yang akan diuji coba adalah: validitas tes, reliabelitas tes, indeks kesukaran tes, dan daya pembeda tes.

\section{G. Teknik Analisis Data}

Analisis data bertujuan untuk mengolah data yang diperoleh dari penelitian, untuk dapat dipertanggung jawabkan kebenarannya. Oleh karena itu perlu dihitung rata-rata (M) dan standart deviasi (SD) dari masing-masing variabel penelitian. Setelah data setiap variabel penelitian terkumpul, maka data tersebut segera ditabulasi dan diolah sesuai dengan tujuan penelitian menggunakan program Microsoft Excel, dan selanjutnya dianalisis secara statistik.

\section{Deskripsi Data Penelitian}

Untuk mengetahui keadaan dari penelitian yang sudah diperoleh, maka terlebih dahulu dihitung besaran dari rata-rata skor (M) dan besaran dari standart deviasi (SD).

\section{Uji Kecenderungan}

Untuk mengetahui kategori keenderungan dari data hasil belajar Menggambar Dengan Perangkat Lunak dan kemampuan menggambar teknik dilakukan uji kecenderungan dengan langkah-langkah sebagai berikut :

a. Dihitung skor tertinggi ideal (Stt) dan skor terendah ideal (Str). 
b. Dihitung rata-rata skor ideal (Mi) dan standart deviasi ideal (SDi), sebagai berikut:

$$
\begin{gathered}
M i=\frac{S t t+S t r}{2} \\
S D i=\frac{S t t-S t r}{6}
\end{gathered}
$$

c. Dari besaran Mi dan Di yang diperoleh dapat ditentukan empat kategori kecenderungan sebagai berikut :

1) $>\mathrm{Mi}=1,5 \mathrm{SDi}$ kategori cenderung tinggi.

2) $\mathrm{Mi} \mathrm{s} / \mathrm{d} \mathrm{Mi} \mathrm{+} \mathrm{1,5} \mathrm{SDi} \mathrm{kategori}$ cenderung sedang.

3) $\mathrm{Mi}-1,5 \mathrm{SDi} / \mathrm{d} \mathrm{Mi}$ kategori cenderung kurang.

4) $<\mathrm{Mi}-1,5 \mathrm{SDi}$ kategori cenderung rendah.

\section{Uji Persyaratan Analisis}

Agar data penelitian yang diperoleh dapat dipakai dengan menggunakan analisis statistika, pada uji hipotesis penelitian yang menerapkan rumus Korelasi Product Moment, maka terlebih dahulu memenuhi persyaratan analisis. Uji persyaratan analisis yang dilakukan adalah untuk mengetahui apakah data penelitian sudah mempunyai sebaran normal serta untuk mengetahui apakah data variabel bebas (X) linear terhadap data variabel terikat $(\mathrm{Y})$, untuk itu dilakukan uji normalitas dan uji linearitas.

a. Uji normalitas

Untuk uji normalitas terhadap data ubahan penelitian dilakukan dengan menggunakan rumus chi-kuadrat seperti yang dikemukakan Arikunto (2002:259).

\section{b. Uji Linearitas}

Untuk mengetahui apakah data variabel bebas (X) linear terhadap data variabel terikat (Y), dilakukan dengan uji regresi linear sederhana Y atas X (Sudjana, 1992).

\section{c. Mencari Persamaan Regresi Ganda}

Sedangkan untuk mengetahui apakah data veriabel bebas $\left(\mathrm{X}_{1}\right.$ dan $\left.\mathrm{X}_{2}\right)$ linear terhadap data variabel terikat $(\mathrm{Y})$ dilakukan uji regresi linear ganda $\mathrm{Y}$ atas $\mathrm{X}_{1}$ dan $\mathrm{X}_{2}$.

\section{d. Uji Hipotesis}

Adapun teknik yang digunakan peneliti dalam menganalisis data penelitian ini adalah teknik analisis data korelasi yaitu teknik korelasi product momen yang dikemukakan oleh Karl Pearson. Teknik ini digunakan untuk menguji variabel $\mathrm{X}$ dan variabel $\mathrm{Y}$ dalam penelitian ini yaitu 1) Hubungan Minat Belajar dengan hasil belajar Menggambar Dengan
Perangkat Lunak, 2) Hubungan Pengetahuan Menggambar Teknik dengan hasil belajar Menggambar Dengan Perangkat Lunak.

\section{HASIL PENELITIAN}

Dalam penelitian ini data yang diambil ada tiga jenis yaitu: Minat Belajar $\left(\mathrm{X}_{1}\right)$ dengan menggunakan instrumen penelitian (angket), Pengetahuan Menggambar Teknik $\left(\mathrm{X}_{2}\right)$ dengan menggunakan instrumen penelitian (tes, multiple choice), dan Hasil Belajar Menggambar Dengan Perangkat Lunak (Y) dengan menggunakan instrumen penelitian (tes; multiple choice dan tes perbuatan). Berdasarkan pengolahan data akan diuraikan berurutan tentang deskripsi data, tingkat kecenderungan masing-masing variabel penelitian, pengujian persyaratan analisis, dan pengujian hipotesis.

\section{A. Deskripsi Data Penelitian}

\section{Minat Belajar $\left(\mathbf{X}_{1}\right)$}

Berdasarkan data variabel Minat Belajar $\left(\mathrm{X}_{1}\right)$ yang diperoleh dengan jumlah responden 32 orang siswa, skor tertinggi 83; skor terendah 32; dengan mean $(\mathrm{M})=53,250$; dan standart deviation $(\mathrm{SD})=10,580 ;$ dengan rentang $(\mathrm{R})=51$; banyak kelas $(\mathrm{BK})=6$; dan panjang kelas $(\mathrm{P})=9$.

2. Pengetahuan Menggambar Teknik $\left(X_{2}\right)$

Berdasarkan data variabel Pengetahuan Menggambar Teknik $\left(\mathrm{X}_{2}\right)$ yang diperoleh dengan jumlah responden 32 orang siswa, skor tertinggi 26; skor terendah 7; dengan mean $(\mathrm{M})=15,969$; dan standart deviation $(\mathrm{SD})=$ 4,476; dengan rentang $(\mathrm{R})=19$; banyak kelas $(\mathrm{BK})=6$; dan panjang kelas $(\mathrm{P})=3$.

\section{Hasil Belajar Menggambar Dengan Perangkat Lunak (Y)}

Berdasarkan data variabel Hasil Belajar Menggambar Dengan Perangkat Lunak (Y) yang diperoleh dengan jumlah responden 32 orang siswa, nilai tertinggi 83,46; nilai terendah 60,58; dengan mean $(\mathrm{M})=70,964$; dan standart deviation $(\mathrm{SD})=4,559$; dengan rentang $(\mathrm{R})=23$; banyak kelas $(\mathrm{BK})=6$; dan panjang kelas $(\mathrm{P})=4$.

\section{B. Identifikasi Tingkat Kecenderungan}

Untuk mengetahui tingkat kecenderungan setiap ubahan penelitian digunakan rata-rata ideal daan standart ideal yang dikategorikan yaitu: tinggi, cukup, kurang, dan rendah.

\section{Tingkat Kecenderungan Ubahan Minat Belajar $\left(\mathbf{X}_{1}\right)$}


Diperoleh Mean Ideal (Mi) ubahan Minat Belajar $\left(\mathrm{X}_{1}\right)$ sebesar 60 dan Standart Deviasi (Sdi) sebesar 12.

Diperoleh tingkat kecenderungan bahwa jumlah responden yang termasuk kategori nilai tinggi sebanyak 1 orang $(3,13 \%)$, kategori cukup sebanyak 19 orang $(59,38 \%)$, kategori kurang sebanyak 12 orang $(37,50 \%)$, dan kategori rendah tidak ada. Dengan demikian Minat Belajar siswa kelas XI Program Keahlian Teknik Gambar Bangunan SMK Negeri 1 Lubuk Pakam Tahun Ajaran 2014/2015 termasuk kategori cukup.

\section{Tingkat Kecenderungan Ubahan}

Pengetahuan Menggambar Teknik $\left(\mathbf{X}_{2}\right)$

Diperoleh Mean Ideal (Mi) ubahan Pengetahuan Menggambar Teknik $\left(\mathrm{X}_{2}\right)$ sebesar 10 dan Standart Deviasi (Sdi) sebesar 3,33 .

Diperoleh tingkat kecenderungan bahwa jumlah responden yang termasuk kategori nilai tinggi sebanyak 5 orang $(15,63 \%)$, kategori cukup sebanyak 15 orang $(46,88 \%)$, kategori kurang sebanyak 12 orang $(37,50 \%)$, dan kategori rendah tidak ada. Dengan demikian Pengetahuan Menggambar Teknik siswa kelas XI Program Keahlian Teknik Gambar Bangunan SMK Negeri 1 Lubuk Pakam Tahun Ajaran 2014/2015 termasuk kategori cukup.

\section{Tingkat Kecenderungan Ubahan Hasil}

\section{Belajar Menggambar Dengan}

Perangkat Lunak (Y)

Diperoleh Mean Ideal (Mi) ubahan Hasil Belajar Menggambar Dengan Perangkat Lunak (Y) sebesar 55 dan Standart Deviasi (Sdi) sebesar 15.

Diperoleh tingkat kecenderungan bahwa jumlah responden yang termasuk kategori tinggi sebanyak 4 orang $(12,50 \%)$, kategori cukup sebanyak 28 orang $(87,50 \%)$, kategori kurang sebanyak tidak ada, dan kategori rendah tidak ada. Dengan demikian kecenderungan Hasil Belajar Menggambar Dengan Perangkat Lunak siswa kelas XI Program Keahlian Teknik Gambar Bangunan SMK Negeri 1 Lubuk Pakam Tahun Ajaran 2014/2015 termasuk kategori cukup.

\section{Uji Persyaratan Analisis}

Dalam pengujian analisis statika untuk menguji hipotesis, maka terlebih dahulu dilakukan Uji Normalitas dan Uji Linearitas untuk melihat terpenuhi atau tidak distribusi data yang normal pada tiap variabel penelitian dan linear atau tidak linear tiap hubungan variabel bebas dan variabel terikatnya.

\section{Uji Normalitas Variabel Penelitian}

Tujuan dilakukan uji normalitas adalah untuk mengetahui normal atau tidak normalnya data penelitian tiap variabel penelitian. Pengujian ini dilakukan dengan menggunakan rumus Chi kuadrat. Syarat normal dipenuhi apabila $\chi_{\text {hitung }}<\chi_{\text {tabel }}$. Dalam penelitian ini ditetapkan signifikansi $5 \%$. Normal atau tidak normalnya data ditentukan dengan mengkonsultasikan harga $\chi_{\text {hitung }}$ yang diperoleh dengan taraf $\chi_{\text {tabel }}$ dengan taraf signifikansi $5 \%$. Berikut ini disajikan hasil analisis dari variabel penelitian yang perhitungan selengkapnya dapat dilihat pada Lapiran 19.

Tabel 11. Ringkasan Hasil Analisis Normalitas Variabel Penelitian

\begin{tabular}{|c|l|c|c|}
\hline No. & \multicolumn{1}{|c|}{ Variabel Penelitiaan } & $\chi_{\text {tabel }}$ \\
\hline 1 & Minat Belajar $\left(\mathrm{X}_{1}\right)$ & 1,850 & \multirow{2}{*}{11,070} \\
\cline { 1 - 2 } 2 & $\begin{array}{l}\text { Pengetahuan Menggambar } \\
\text { Teknik }\left(\mathrm{X}_{2}\right)\end{array}$ & 5,920 & \\
\cline { 1 - 2 } 3 & $\begin{array}{l}\text { Hasil Belajar Menggambar } \\
\text { Dengan Perangkat Lunak (Y) }\end{array}$ & 8,783 & \\
\hline
\end{tabular}

Pada Tabel 11 diperoleh bahwa $\chi_{\text {hitung }}<$ $\chi_{\text {tabel }}$ pada taraf signifikansi 5\%. Dengan demikian dapat disimpulkan bahwa data Minat Belajar $\left(\mathrm{X}_{1}\right)$, Pengetahuan Menggambar Teknik $\left(\mathrm{X}_{2}\right)$, dan Hasil Belajar Menggambar Dengan Perangkat Lunak (Y) adalah berdistribusi normal.

\section{Uji Linearitas dan Keberartian Regresi}

a. Uji Linearitas $\mathbf{Y}$ atas $\mathrm{X}_{1}$

Berikut ini pada Tabel 4.8 disajikan ringkasan analisis varians yang menguji kelinearan dan keberartian persamaan regresi Hasil Belajar Menggambar Perangkat Lunak (Y) atas Minat Belajar $\left(\mathrm{X}_{1}\right)$. Diperoleh persamaan regresi $\mathrm{Y}$ atas $\mathrm{X}_{1}$, yaitu:

$$
Y=70,522+0,190 X_{1}
$$

Diperoleh $F_{\text {tabel }}$ dengan db (19:11) pada taraf signifikansi 5\% adalah 2,510 sedangkan $\mathrm{F}_{\text {hitung }}$ yang diperoleh adalah 0,880 . Ternyata $F_{\text {hitung }}<\mathrm{F}_{\text {tabel }}(0,880<2,510)$ sehingga persamaan regresi $\mathbf{Y}=\mathbf{7 0 , 5 2 2}+\mathbf{0 . 1 9 0} \mathbf{X}_{1}$ adalah linear pada taraf signifikansi $5 \%$. Selanjutnya untuk Uji Keberartian dan Persamaan Regresi, $F_{\text {tabel }}$ dengan dk (1:30) pada taraf signifikansi $5 \%$ adalah 4.170 sedangkan $\mathrm{F}_{\text {hitung }}$ yang diperoleh adalah 5,105. Ternyata $\mathrm{F}_{\text {hitung }}>\mathrm{F}_{\text {tabel }}(5,105>4.170)$ sehingga persamaan regresi tersebut adalah berarti. Dengan demikian dapat disimpulkan bahwa koefisien arah persamaan regresi $\mathrm{Y}$ atas $\mathrm{X}_{1}$ mempunyai hubungan yang linear dan berarti pada taraf signifikansi $5 \%$. 


\section{b. Uji Linearitas $\mathbf{Y}$ atas $\mathbf{X}_{2}$}

Berikut ini pada Tabel 12 disajikan ringkasan analisis varians yang menguji kelinearan dan keberartian persamaan regresi Hasil Belajar Menggambar Perangkat Lunak (Y) atas Pengetahuan Menggambar Teknik $\left(\mathrm{X}_{2}\right)$. Diperoleh persamaan regresi $\mathrm{Y}$ atas $\mathrm{X}_{2}$, yaitu:

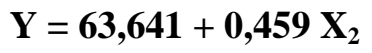

Diperoleh $\mathrm{F}_{\text {tabel }}$ dengan $\mathrm{db}(15: 15)$ pada taraf signifikansi $5 \%$ adalah 2,510 sedangkan $\mathrm{F}_{\text {hitung }}$ yang diperoleh adalah 1,823 . Ternyata $\mathrm{F}_{\text {hitung }}<\mathrm{F}_{\text {tabel }}(1,823<2,510)$ sehingga persamaan regresi $Y=63,641+0.459 X_{2}$ adalah linear pada taraf signifikansi $5 \%$. Selanjutnya untuk Uji Keberartian dan Persamaan Regresi, $F_{\text {tabel }}$ dengan dk (1:30) pada taraf signifikansi 5\% adalah 4.17 sedangkan $\mathrm{F}_{\text {hitung }}$ yang diperoleh adalah 7,634. Ternyata $F_{\text {hitung }}>F_{\text {tabel }}(7,643>4.17)$ sehingga persamaan regresi tersebut adalah berarti. Dengan demikian dapat disimpulkan bahwa koefisien arah persamaan regresi $\mathrm{Y}$ atas $\mathrm{X}_{2}$ mempunyai hubungan yang linear dan berarti pada taraf signifikansi $5 \%$.

\section{Uji Hipotesis Penelitian}

\section{Hubungan antara Minat Belajar dengan Hasil Belajar Mengggambar Perangkat Lunak \\ Dari perhitungan Korelasi Product} Moment diperoleh koefisien korelasi antara $\mathrm{X}_{1}$ dengan $\mathrm{Y}=0.441$; sedangkan $\mathrm{r}_{\text {tabel }}$ dengan $\mathrm{N}=$ 32 dan taraf signifikansi 5\% sebesar 0.349 . Dengan demikian harga $r_{X 1 Y}>r_{\text {tabel }}(0.441>$ 0.349). Selanjutnya dilakukan uji keberartian korelasi dengan menggunakan Uji-t diperoleh $t_{\text {hitung }} 3,000$. Harga $t_{\text {tabel }}$ untuk $N=32$ pada taraf signifikansi 5\% adalah 1.696. Oleh karena $t_{\text {hitung }}>t_{\text {tabel }}(3,000>1.696)$ maka dapat dikatakan bahwa terdapat hubungan antara Minat Belajar $\left(\mathrm{X}_{1}\right)$ dengan Hasil Belajar Mengggambar Perangkat Lunak (Y).

Selanjutnya untuk melihat hubungan murni tanpa variabel bebas lainnya, dilakukan Uji Korelasi Parsial. Diperoleh koefisien korelasi parsial antara $\mathrm{X}_{1}$ dengan $\mathrm{Y}=0.523$; sedangkan $r_{\text {tabel }}$ dengan dengan $\mathrm{N}=32$ dan taraf signifikansi 5\% adalah 0.349 . Selanjutnya dilakukan uji keberartian korelasi parsial dengan menggunakan Uji-t diperoleh $\mathrm{t}_{\text {hitung }}=3,305$. Harga $\mathrm{t}_{\text {tabel }}$ untuk $\mathrm{N}=32$ pada taraf signifikansi $5 \%$ adalah 1.696. Oleh karena $t_{\text {hitung }}>t_{\text {tabel }}(3,305>1.696)$ maka dapat dikatakan terdapat hubungan antara Minat Belajar dengan Hasil Belajar Mengggambar
Perangkat Lunak, dengan variabel Pengetahuan Menggambar Teknik dikontrol.

Dari hasil perhitungan di atas, dapat disimpulkan hipotesis penelitian yang diajukan bahwa terdapat hubungan yang positif dan berarti antara Minat Belajar dengan Hasil Belajar Menggambar Perangkat Lunak serta teruji kebenarannya.

\section{Hubungan antara Pengetahuan Menggambar Teknik dengan Hasil Belajar Mengggambar Perangkat Lunak \\ Dari perhitungan Korelasi Product} Moment diperoleh koefisien korelasi antara $\mathrm{X}_{2}$ dengan $\mathrm{Y}=0.450$; sedangkan $\mathrm{r}_{\text {tabel }}$ dengan $\mathrm{N}=$ 32 dan taraf signifikansi 5\% sebesar 0.349 . Dengan demikian harga $r_{X 2 Y}>r_{\text {tabel }}(0.450>$ 0.349). Selanjutnya dilakukan uji keberartian korelasi dengan menggunakan Uji-t diperoleh $t_{\text {hitung }} 3,093$. Harga $t_{\text {tabel }}$ untuk $N=32$ pada taraf signifikansi 5\% adalah 1.696. Oleh karena $t_{\text {hitung }}>t_{\text {tabel }}(3,093>1.696)$, maka dapat dikatakan bahwa terdapat hubungan antara Minat Belajar $\left(\mathrm{X}_{1}\right)$ dengan Hasil Belajar Mengggambar Perangkat Lunak (Y).

Selanjutnya untuk melihat hubungan murni tanpa variabel bebas lainnya, dilakukan Uji Korelasi Parsial. Diperoleh koefisien korelasi parsial antara $\mathrm{X}_{2}$ dengan $\mathrm{Y}=0,546$; sedangkan $r_{\text {tabel }}$ dengan dengan $\mathrm{N}=32$ dan taraf signifikansi 5\% adalah 0,349. Selanjutnya dilakukan uji keberartian korelasi parsial dengan menggunakan Uji-t diperoleh $\mathrm{t}_{\text {hitung }}=3,508$. Harga $\mathrm{t}_{\text {tabel }}$ untuk $\mathrm{N}=32$ pada taraf signifikansi 5\% adalah 1,696. Oleh karena $t_{\text {hitung }}>t_{\text {tabel }}(3,508>1,696)$ maka dapat dikatakan terdapat hubungan antara Pengetahuan Menggambar Teknik dengan Hasil Belajar Mengggambar Perangkat Lunak, dengan variabel Minat Belajar dikontrol.

Dari hasil perhitungan di atas, dapat disimpulkan hipotesis penelitian yang diajukan bahwa terdapat hubungan yang positif dan berarti antara Pengetahuan Menggambar Teknik dengan Hasil Belajar Menggambar Perangkat Lunak serta teruji kebenarannya.

3. Hubungan antara Minat Belajar dan Pengetahuan Menggambar Teknik dengan Hasil Belajar Mengggambar Perangkat Lunak

Dari perhitungan korelasi ganda diperoleh koefisien korelasi antara $\mathrm{X}_{1}$ dan $\mathrm{X}_{2}$ dengan $\mathrm{Y}$ yaitu $\mathrm{R}_{\mathrm{Y}(1,2)}=0,502$; sedangkan $\mathrm{r}_{\text {tabel }}$ dengan $\mathrm{N}$ $=32$ pada taraf signifikansi $5 \%$ sebesar 0,349. Dengan demikian harga $\mathrm{R}_{\mathrm{Y}(1,2)}>\mathrm{r}_{\text {tabel }}(0,502>$ 
0,349). Selanjutnya dilakukan uji keberartian korelasi dengan menggunakan Uji-F diperoleh $F_{\text {hitung }}=4,846$. Harga $F_{\text {tabel }}$ untuk $N=32$ pada taraf signifikansi adalah 3,333. Oleh karena $\mathrm{F}_{\text {hitung }}>\mathrm{F}_{\text {tabel }}(4,846>3,333)$, maka dapat dikatakan bahwa hipotesis penelitian yang diajukan yakni terdapat hubungan yang positif dan berarti antara Minat Belajar dan Pengetahuan Menggambar Teknik dengan Hasil Belajar Menggambar Perangkat Lunak dapat diterima dan teruji kebenarannya.

\section{E. Temuan Penelitian}

Dalam penelitian ini ditemukan bahwa terdapat hubungan yang positif dan berarti antara Minat Belajar dengan Hasil Belajar Menggambar Perangkat Lunak siswa kelas XI Program Keahlian Teknik Gambar Bangunan SMK Negeri 1 Lubuk Pakam Tahun Ajaran 2014/2015. Temuan ini menunjukkan bahwa Minat Belajar mempengaruhi Hasil Belajar Menggambar Perangkat Lunak siswa.

Selanjutnya dalam penelitian ini ditemukan bahwa terdapat hubungan yang positif dan berarti antara Pengetahuan Menggambar Teknik dengan Hasil Belajar Menggambar Perangkat Lunak siswa kelas XI Program Keahlian Teknik Gambar Bangunan SMK Negeri 1 Lubuk Pakam Tahun Ajaran 2014/2015. Temuan ini menunjukkan bahwa Pengetahuan Menggambar Teknik mempengaruhi Hasil Belajar Menggambar Perangkat Lunak siswa.

\section{KESIMPULAN, IMPLIKASI, DAN SARAN}

\section{A. Kesimpulan Penelitian}

Berdasarkan hasil penelitian pada Bab sebelumnya, maka dapat disimpulkan bahwa:

1. Terdapat hubungan yang positif dan berarti antara Minat Belajar dengan Hasil Belajar Menggambar Dengan Perangkat Lunak pada siswa kelas XI Program Keahlian Teknik Gambar Bangunan SMK Negeri 1 Lubuk Pakam Tahun Ajaran 2014/2015 dengan besar korelasi $\mathrm{r}_{\mathrm{X} 1 \mathrm{Y}}=$ 0.441 dan uji keberartian diperoleh $t_{\text {hitung }}$ $>t_{\text {tabel }}(3,000>1.696)$. Selanjutnya untuk melihat hubungan murni diperoleh koefisien korelasi parsial $\mathrm{r}_{\mathrm{X} 1 \mathrm{Y}}=0.523>$ $\mathrm{r}_{\text {tabel }}$ dengan dengan $\mathrm{N}=32$ dan taraf signifikansi $5 \%$ adalah 0.349 . Untuk uji keberartian korelasi parsial diperoleh $\mathrm{t}_{\text {hitung }}>\mathrm{t}_{\text {tabel }}(3,305>1.696)$.

2. Terdapat hubungan yang positif dan berarti antara Pengetahuan Menggambar
Teknik dengan Hasil Belajar Menggambar Dengan Perangkat Lunak pada siswa kelas XI Program Keahlian Teknik Gambar Bangunan SMK Negeri 1 Lubuk Pakam Tahun Ajaran 2014/2015 dengan besar korelasi $\mathrm{r}_{\mathrm{X} 2 \mathrm{Y}}=0.450$ dan uji keberartian diperoleh $t_{\text {hitung }}>t_{\text {tabel }}(3,093>$ 1.696). Selanjutnya untuk melihat hubungan murni diperoleh koefisien korelasi parsial $r_{X 2 Y}=0,546>r_{\text {tabel }}$ dengan dengan $\mathrm{N}=32$ dan taraf signifikansi $5 \%$ adalah 0,349 . Untuk uji keberartian korelasi parsial diperoleh $t_{\text {hitung }}>t_{\text {tabel }}(3,508>1,696)$.

3. Terdapat hubungan yang positif dan berarti antara Minat Belajar dan Pengetahuan Menggambar Teknik dengan Hasil Belajar Menggambar Dengan Perangkat Lunak pada siswa kelas XI Program Keahlian Teknik Gambar Bangunan SMK Negeri 1 Lubuk Pakam Tahun Ajaran 2014/2015 dengan besar korelasi $r_{Y(1,2)}=0,502>r_{\text {tabel }}$ dengan $\mathrm{N}=$ 32 pada taraf signifikansi $5 \%$ sebesar 0,349 . Selanjutnya untuk uji keberartian korelasi diperoleh $\mathrm{F}_{\text {hitung }}=4,846>\mathrm{F}_{\text {tabel }}$ untuk $\mathrm{N}=32$ pada taraf signifikansi adalah 3,333.

\section{B. Implikasi Penelitian}

Berdasarkan hasil penelitian dan kesimpulan penelitian yang ditemukan, adapun implikasi penelitian yang dapat dinyatakan mengenai Minat Belajar dan Pengetahuan Menggambar Teknik dengan Hasil Belajar Menggambar Dengan Perangkat Lunak yaitu:

1. Dengan diterimanya hipotesis pertama, maka upaya meningkatkan Hasil Belajar Menggambar Dengan Perangkat Lunak adalah dengan meningkatkan Minat Belajar siswa. Upaya yang dapat dilakukan guru adalah dengan memberikan dorongan dalam berinteraksi dengan lingkungannya, menarik perhatian siswa sewaktu mengajar, memberi petunjuk dalam melakukan aktivitas dan membuat siswa merasa senang dalam melakukan aktivitas. Dengan adanya upaya ini, minat belajar dapat ditingkatkan.

2. Dengan diterimanya hipotesis kedua, maka upaya meningkatkan Hasil Belajar Menggambar Dengan Perangkat Lunak adalah dengan meningkatkan Pengetahuan Menggambar Teknik siswa. Upaya yang dapat dilakukan guru adalah 
memberikan latihan-latihan belajar dalam penguasaan tentang materi gambar teknik, misalnya dengan memberikan latihan menggunakan rol segitiga sepasang, sablon, rapido, jangka dengan harapan siswa lebih aktif di dalam kegiatan proses belajar di kelas, sehingga dapat mendukung hasil belajar menggambar teknik siswa.

3. Dengan diterimanya hipotesis ketiga, maka upaya meningkatkan Hasil Belajar Menggambar Dengan Perangkat Lunak adalah dengan meningkatkan Minat Belajar dan Pengetahuan Menggambar Teknik siswa. Upaya yang dapat dilakukan guru adalah meningkatkan kualitas pengajaran, penggunaan metode yang sesuai, salah satunya dengan menggunakan peningkatan pengetahuan siswa tentang materi pengajaran, memberikan pengarahan kepada siswa tentang pentingnya menumbuhkan minat belajar pada diri yang berhubungan dengan mata pelajaran Menggambar Dengan Perangkat Lunak.

\section{Saran Penelitian}

Berdasarkan kesimpulan dan implikasi penelitian di atas, maka penulis menyarankan:

1. Dengan diperolehnya koefisien korelasi antara variabel Minat Belajar dengan Hasil Belajar Menggambar Dengan Perangkat Lunak sebesar 44,1\%. Untuk memaksimalkan Hasil Belajar Menggambar Dengan Perangkat Lunak hingga $100 \%$, penulis menyarankan untuk dilakukan penelitian berikutnya dengan variabel lain, seperti motivasi belajar dan persepsi tentang lingkungan belajar.

2. Dengan diperolehnya koefisien korelasi antara variabel Pengetahuan Menggambar Teknik dengan Hasil Belajar Menggambar Dengan Perangkat Lunak sebesar 45\%. Untuk memaksimalkan Hasil Belajar Menggambar Dengan Perangkat Lunak hingga $100 \%$, penulis menyarankan untuk dilakukan penelitian berikutnya dengan variabel lain, seperti kreativitas menggambar siswa dan sumber belajar siswa.

3. Untuk meningkatkan Hasil Belajar Menggambar Dengan Perangkat Lunak, diharapkan peran serta Sekolah dan Guru untuk menciptakan lingkungan belajar yang mendukung, memotivasi siswa, memberikan penjelasan tentang pentingnya mata pelajaran Menggambar Perangkat Dengan Lunak terhadap mata pelajaran lainnya.

\section{DAFTAR PUSTAKA}

Ahmadi, Abu. 1991. Psikologi Umum. Jakarta, Rineka Cipta

Arikunto, Suharsimi. 2002. Prosedur Penelitian. Jakarta, Bina Aksara

Hadjar, Ibnu. 1996. Dasar-Dasar Metodologi Penelitian Kuantitatif dalam Pendidikan. Surabaya, Usaha Nasional Haspah, Sudin. 2008. Hubungan Minat Belajar dan Kreativitas Menggambar Teknik Terhadap Hasil Belajar Menggambar Autocad Siswa Kelas III Program Keahlian Teknik Gambar Bangunan SMK Negeri 1 Percut Sei Tuan. Medan, Universitas Negeri Medan

Hurlock, Elezabeth B. 1996. Perkembangan Anak. Jakarta, Erlangga

Laseau, Paul. 1986. Berpikir Gambar bagi Arsitek dan Perancang. Bandung, Penerbit ITB Bandung

Mukomoko. 1996. Dasar-Dasar Penyusunan Anggaran Biaya Bangunan. Jakarta, Gaya Media

Natawidjaya. 1989. Psikologi Pendidikan. Bandung, Abadi

Purwanto, Gandung, Raharjo, Tentrem. 2001. Menggambar Teknik Dasar. Yogyakarta, Penerbit Kanisius

Rahman. 1999. Gaya Belajar. Jakarta, Rineka Cipta

Sabri, Ahmad. 2010. Strategi Belajar Mengajar dan Micro Teaching. Padang, Quantum Teaching

Sardiman. 2005. Interaksi dan Motivasi Belajar Mengajar. Jakarta, Rajawali Pers

Slameto. 2003. Belajar dan Faktor-Faktor yang Menpengaruhinya. Jakarta, Rineka Cipta

Slameto. 2010. Belajar dan Faktor-Faktor yang Menpengaruhinya. Jakarta, Rineka Cipta

Soermajadi, dkk. 1991. Pendidikan Keterampilan. Jakarta, Departemen Pendidikan dan Kebudayaan Direktorat Jenderal Pendidikan Tinggi Proyek Pembinaan Tenaga Kependidikan 
Soma, Hari Aria. 2002. Mahir Menggunakan AutoCAD Release 14. Jakarta, Elex Media Komputindo

Sudijono, Anas. 2001. Pengantar Statistik Pendidikan. Jakarta. RajaGrafindo Persada.

Sudjana. 2002. Metode Statistik. Bandung, Tarsito

Sugiyono. 2008. Metode Penelitian Pendidikan Pendekatan Kuantitatif, Kualitatif dan R\&D. Bandung, Alfabeta

Walgito, Bimo. 2004. Pengantar Psikologi Umum. Yogyakarta, Penerbit Andi

Walpole, E. Ronald. 1995. Pengantar Statistika. Jakarta, Gramedia Pustaka Utama

Winkel. W. S. 1996. Psikologi Pengajaran. Jakarta, Gramedia

Witheringthon. H. C. 1987.Psikologi Pendidikan. Jakarta, Rineka Ci 